\title{
Mechanikai aktiválás hatása
}

\section{deponált pernye alapú geopolimerek nyomószilárdságára}

AMBRUS MÁRIA - Miskolci Egyetem, Nyersanyagelốkészítési és Környezeti Eljárástechnikai Intézet - maria.ambrus@uni-miskolc.hu

Érkezett: 2019. 07. 30. - Received: 30. 07. 2019. - https://doi.org/10.14382/epitoanyag-jsbcm.2019.26

\section{Kivonat}

Az elsôdleges nyersanyagforrások növekvô felhasználása és folyamatos csökkenése miatt a pernye napjaink egyik meghatározó nyersanyagává vált többek között cement- és betonipari, mezôgazdasági stb. felhasználásra. A pernye geopolimer alapanyagként való felhasználása már évtizedek óta foglalkoztatja a kutatókat. Jó reakcióképessége és a termékek kiváló mechanikai tulajdonságai mellett alkalmazása környezeti szempontból is elônyös. Kísérleteim során tatabányai, deponált barnaszén pernye ốrlésének hatását vizsgáltam az ezekből készült geopolimerek nyomószilárdságára. A pernye fốbb tulajdonságainak meghatározása után 5, 10, 20, 30, 60 és 120 perces ôrleményeket készítettem, melyekből geopolimer próbatesteket állítottam elô. Az ôrlési idố növelésének hatására nôtt a próbatestek testsưrúségének értéke, azonban az egytengelyú nyomószilárdság esetén nem volt megfigyelhetô egyértelmú trend: kezdeti növekedés után a geopolimerek nyomószilárdsága csökkent, majd ismét megnövekedett. Annak érdekében, hogy feltárjam a változások okát az alapanyag és a próbatestek vizsgálata mellett eredményeimet összehasonlítottam korábbi deponált pernyébốl (tiszaújvárosi) elôállított geopolimerek tulajdonságaival. Az eddig elvégzett vizsgálatok alapján látható, hogy minden pernye esetében van egy optimális ôrlési finomság.

Kulcsszavak: deponált pernye, geopolimer, mechanikai aktiválás, nyomószilárdság

Keywords: compressive strength, geopolymer, landfilled fly ash, mechanical activation

\section{Bevezetés}

Világviszonylatban a cement az egyik legnagyobb mennyiségben használt alapanyag. Felhasználása a társadalmi-gazdasági fejlődés elengedhetetlen velejárója, azonban eloóllítása nagy mennyiségű $\mathrm{CO}_{2}$ kibocsátással jár (pl. kemencefütés, mészkő kalcinálás, alapanyag szállítás stb.), ezért az utóbbi évtizedek során világszerte kutatásokat végeznek környezetbarát, alternatív építőanyagok kifejlesztésére [1,2]. A geopolimerek szervetlen, polimer szerkezetű anyagok, melyek szilárd alumino-szilikátoxidok és alkáli-szilikátok lúgos vagy savas közegben történő aktiválásával állíthatók elő. Energiahatékony és környezetbarát előállításuk, kiváló mechanikai tulajdonságaik, bizonyított savés tűzállóképességük miatt ideális építőipari alapanyagnak bizonyultak. Szerkezetük az alábbi képlettel jellemezhető:

$$
\mathrm{Mn}\left\{-\left(\mathrm{Si}-\mathrm{O}_{2}\right) \mathrm{z}-\mathrm{Al}-\mathrm{O}\right\} \mathrm{n} \cdot \mathrm{wH}_{2} \mathrm{O}
$$

ahol „M” a töltéskiegyenlítéshez szükséges kation, leggyakrabban $\mathrm{Na}^{+}, \mathrm{K}^{+}, \mathrm{az}$ „n” a polikondenzációs fok, „Z” jelöli a Si/Al moláris arányt, ami 1, 2 vagy 3 lehet, illetve „w" a kapcsolódó vízmolekulák számára utal [2-4].

A pernye a széntüzelésű erőművekben keletkező, finom szemcseméretü, világszerte nagy mennyiségben fellelhető ipari melléktermék. Miután a szén elégetése után a füstgázzal távozik a kazánból, a pernyét különböző porleválasztók segítségével (elektrosztatikus porleválasztó, mechanikai szürő, vagy ciklon) eltávolítják a rendszerből. Ezt követően hasznosítható pl. talajjavítóként vagy cement- és betonipari alapanyagként, de legnagyobb mennyiségbe lerakásra/tárolásra kerül. Kémiai és ásványos összetétele alapján megfelelő geopolimerizációs alapanyag, felhasználása környezeti és gazdasági szempontból is elönyös $[1,5,6]$.
Az elmúlt évtizedekben elvégzett, pernye-alapú geopolimer gyártásra irányuló kísérletek során kezeletlen, osztályozott (pl. szitálással, légosztályozóval) és mechanikailag aktivált pernye alkalmazását is vizsgálták $[7,8,9]$, azonban a szakirodalom kis hányada foglalkozik a deponált pernye felhasználásának lehetőségeivel.

Kusnierová és szerzőtársai deponált feketeszén pernye amorf fázis tartalmának változását vizsgálták az eltelt idő függvényében és megállapították, hogy a pernye jelentős devitrifikáción ment keresztül, azaz csökkent az üveges fázis aránya [10]. Yehevis et al. kutatásuk során a deponált pernye kémiai, ásványtani és geokémiai változásait elemezték. A minták eltérő ideig, különböző mélységekben voltak deponálva, így az erózió hatását is megfigyelhették. Eredményeik alapján elmondható, hogy a pernye ásványos összetétele és mikroszerkezete megváltozott a deponálás hatására [11]. Peterová et al. deponált és friss pernye anyagtulajdonságait hasonlították össze, hogy megállapítsák, alkalmas-e a több évtizede tárolt pernye betonipari hasznosításra. Vizsgálataikkal kimutatták, hogy a különböző mélységben vett deponált pernye minták szemcseméreteloszlásai tág határok közt mozogtak, így felhasználás előtt szükséges annak osztályozása vagy őrlése [12].

Tennakoon et al. ausztrál deponált és friss barnaszén pernye felhasználási lehetőségeit vizsgálták. Megállapították, hogy a pernyék önmagukban nem alkalmazhatók jó minőségü geopolimer elóállítására az alacsony $\mathrm{SiO}_{2} / \mathrm{Al}_{2} \mathrm{O}_{3}$ arányuk miatt, viszont feketeszén pernye és salak hozzáadásával akár $30 \mathrm{MPa}$ feletti 7 napos nyomószilárdság is elérhető (maximum $40 \%$ barnaszén pernye használatával). Ezen keverékek esetén a deponált barnaszén pernyét tartalmazó próbatestek 
mikroszerkezeti vizsgálatai során kevesebb szabad pernye és salak szemcse volt megfigyelhető, mint friss pernye használata esetén [13]. Saxena et al. kísérleteik során arra következtetett, hogy a deponált pernye alkalmas jó minőségű geopolimer előállítására, továbbá megállapították, hogy 1 órás mikrohullámú hőkezelést alkalmazva magasabb szilárdságú geopolimerek állíthatók elő, mint amit kemencében $80^{\circ} \mathrm{C}$-os, 12 órás hőkezeléssel tudtak elérni [14].

A termikus kezelés mellett fontos az alapanyagok mechanikai előkészítése. Mechanikai aktiválás hatására csökken a szemcseméret és megváltozik szemcsék morfológiája, ezáltal nő a pernye reakcióképessége és nő az előállított geopolimerek nyomószilárdsága [7, 9, 15]. Kwasny et al. nedves, szárított és szitált, szárított és őrölt deponált, valamint silóban tárolt pernye alapú geopolimerek nyomószilárdságát hasonlították össze. Szárított és örölt deponált pernye használatával közel azonos nyomószilárdságú geopolimereket sikerült készíteniük, mint a silóban tárolt pernye alkalmazásával, azonban előkezelés nélkül a reakcióképessége nem volt megfelelő [16]. A Miskolci Egyetem Nyersanyagelőkészítési és Környezeti Eljárástechnikai Intézetében már 10 éve folynak deponált pernye mechanikai aktiválására és hasznosítására irányuló kutatások. Tiszaújvárosi deponált pernye keverőmalommal történő őrléseik során Molnár et al. (2014) az örlési idő növelésével a szemcsék agglomerálódását és a fajlagos felület csökkenését, a szubmikronos szemcsék alakjának változását tapasztalták [17]. Mucsi et al. tiszaújvárosi deponált pernyével folytatott kísérleteik során szintén a szemcsék finomodását, majd agglomerálódását figyelték meg az őrlési idő növelésével, ami a fajlagos felület kezdeti növekedését, majd csökkenését eredményezte. Ez a geopolimer próbatestek testsürüség és nyomószilárdság értékeinél is megfigyelhető volt: kezdeti növekedés után az optimális őrlési időt túllépve mind a nyomószilárdság, mint a testsürüség csökkenni kezdett. Kísérleteik során több malomtípussal is kísérleteztek, ezek közül keverőmalmi őrléssel sikerült a legfinomabb szemcseméretű pernyét előállítaniuk $[18,19]$. Szabó et al. a pernye őrlés geopolimer habokra gyakorolt hatását vizsgálták, tiszaújvárosi pernye használatával. Kutatásaik során sikerült összefüggést felállítaniuk a geopolimer paszta folyási tulajdonsága és a pernye szemcsefinomsága között. Az előállított geopolimer habok nyomószilárdsága és testsűrüsége eleinte nőtt az őrlési idő növelésével, majd csökkenni kezdett [20].

Kísérleteim során golyósmalmi őrlés hatását vizsgáltam tatabányai deponált barnaszén pernyéből készült geopolimerek nyomószilárdságára.

\section{Anyagok, vizsgálati módszerek}

A geopolimerizációs kísérletekhez tatabányai deponált barnaszén pernyét (FA1) használtam, és az elért eredményeket hasonló körülmények közt őrölt, tiszaújvárosi deponált barnaszén pernye (FA2) geopolimerek vizsgálati eredményeivel vetettem össze.

A pernyék kémiai összetételének meghatározása röntgenfluoreszcens spektroszkópia segítségével (XRF) történt, mely eredményét az 1. táblázat foglalja össze. Az XRF eredmények alapján megállapítható, hogy $\mathrm{FA} 2 \mathrm{SiO}_{2}$ tartalma közel 15\%-kal magasabb, azonban $\mathrm{Al}_{2} \mathrm{O}_{3}$ tartalma közel azonos, mint az FA1 mintáé. Ebből adódóan az FA1 minta esetén a $\mathrm{SiO}_{2} / \mathrm{Al}_{2} \mathrm{O}_{3}$ arány jóval alacsonyabb $(1,69)$, mint az FA2 minta esetén $(2,3)$. Összetételük alapján FA1 és FA2 is F típusú pernye, azonban FA1 lényegesen magasabb $\mathrm{CaO}$ tartalommal rendelkezett, mint FA2.

\begin{tabular}{lcc} 
& \multicolumn{1}{c}{ FA1 } & FA2 \\
Komponens & Alkotó mennyisége, $\mathbf{m} / \mathbf{m} \%$ \\
\hline $\mathbf{S i O}_{\mathbf{2}}$ & 46,40 & 61,32 \\
\hline $\mathbf{A l}_{\mathbf{2}} \mathbf{O}_{\mathbf{3}}$ & 27,40 & 26,71 \\
\hline $\mathbf{C a O}$ & 7,04 & 1,50 \\
\hline $\mathbf{F e} \mathbf{O}_{\mathbf{3}}$ & 6,96 & 4,27 \\
\hline $\mathbf{M g O}$ & 2,23 & 0,89 \\
\hline $\mathbf{K} \mathbf{O}_{\mathbf{2}}$ & 1,65 & 1,72 \\
\hline Egyéb & 8,32 & 3,59 \\
\hline LOI* & 0,75 & 1,92 \\
\hline
\end{tabular}

$$
\begin{aligned}
& { }^{*} \text { Izzitási veszteség } 950{ }^{\circ} \mathrm{C} \text {-on (Loss on ignition at } 950{ }^{\circ} \mathrm{C} \text { ). } \\
& \text { 1. táblázat A pernyék kémiai összetétele } \\
& \text { Table } 1 \text { The chemical composition of the fly ash samples, FA1=Tatabánya fly ash, } \\
& \text { FA2=Tiszaújváros fly ash }
\end{aligned}
$$

A pernyék izzítási vesztesége fontos tulajdonság geopolimer előállítás szempontjából. Ha magas a pernye szervesanyag-tartalma, nagyobb mennyiségü aktiváló oldat használata szükséges, ami a geopolimer alacsonyabb nyomószilárdságát eredményezi. A két deponált pernyeminta LOI értéke igen alacsony, az FA1 értéke 1\% alatti, míg az FA2 értéke közel 2\%.

A pernyék mechanikai aktiválása a Nyersanyagelőkészítési és Környezeti Eljárástechnikai Intézet sima falú páncélzattal ellátott, Ø305×305 mm-es golyósmalmában történt. FA1 esetén 5 , 10, 20, 30, 60 és 120 perces örlést alkalmaztam. Az FA2 minták esetén az őrlés 5, 10, 20, 30 és 60 perces volt [19]. Az FA1 örlése során acél őrlőtesteket használtam, melyek össztömege $36 \mathrm{~kg}$ volt 30\%-os töltési fok mellett, a maximális golyóméret pedig $40 \mathrm{~mm}$ volt. A pernyét $110 \%$ anyagtöltési fok és 70 1/min fordulatszám alkalmazásával őröltem. az FA2 minta őrlése azonos körülmények között történt.

Az FA1 geopolimer keverékek szilárd anyag/aktiváló oldat aránya 0,82 volt. Az aktiváló oldat $75 \mathrm{~m} / \mathrm{m} \%$ Betol SB típusú vízüveget $\left(25,3 \% \mathrm{SiO}_{2} ; 13,7 \% \mathrm{Na}_{2} \mathrm{O} ; 2,7 \% \mathrm{~K}_{2} \mathrm{O}\right)$ és $25 \mathrm{~m} / \mathrm{m} \%$ $8 \mathrm{M}$-os $\mathrm{NaOH}$-t tartalmazott. Az FA2 próbatestek 0,65 szilárd anyag/aktiváló oldat ( $\mathrm{NaOH}$ oldat) aránnyal készültek [19].

A geopolimer próbatestek elöállításához elöször összekevertem a pernyét és az aktiváló oldatot, amit $35 \mathrm{~mm}$ belső átmérőjü, formaelválasztó olajjal bekent, hengeres sablonokba töltöttem. Ezután a próbatesteket vibrációs asztal segítségével 1 percig tömörítettem. A tömörített próbatesteket 24 órán át levegőtől elzártan, állandó hőmérsékleten pihentettem, majd a 24 óra eltelte után következett a próbatestek hőkezelése 1 órás felfütési idővel, $50^{\circ} \mathrm{C}$-on, 6 órán keresztül. Ezt követően a hőkezelt geopolimereket lehülés után további 5 napig levegőtől elzártan, állandó hőmérsékleten pihentettem. A próbatestek tömegének, magasságának és átmérőjének mérésével meghatároztam az átlagos testsűrüség értékeket, majd ezután történt a próbatestek egytengelyü nyomószilárdság-vizsgálata.

A nyers és őrölt pernyék szemcseméret-eloszlás méréséhez laboratóriumi HORIBA LA950-V2 típusúlézeres szemcseméret- 
elemző készüléket használtam, nedves közegü diszpergálással. A szemcseméret eloszlás meghatározása mellett a szoftver segítségével lehetséges a mért anyag fajlagos felületének (geometriai), darab-, ill. felületi eloszlásának a meghatározása is. A fajlagos felület számítása 1,75-ös alaktényezővel történt.

A geopolimerek szerkezetének vizsgálatához Jasco FT-IR 4200 típusú Fourier transzformációs infravörös spektrométert használtam.

\section{Eredmények}

\subsection{Pernye őrlés}

$\mathrm{Az}$ őrlések során az őrlési energia mérésére is sor került, mely egyenes arányosságban nőtt az őrlés időtartamával. Az FA1 minta 5, 10, 20, 30, 60 és 120 perces őrlése után mért nevezetes szemcseméretek $\left(\mathrm{x}_{10}, \mathrm{x}_{50}, \mathrm{x}_{90}\right.$ : azok a szemcseméretek, amelynél a szemcsék 10,50, illetve $90 \%$-a kisebb) változását az 1. ábra mutatja. $\mathrm{Az}$ örlemények $\mathrm{x}_{10}$ értéke kis mértékben folyamatosan csökkent az örlés hatására, a 120 perces örlés végére $1,76 \mu \mathrm{m}$-re csökkent. A medián szemcseméret 20 perc után jelentősen csökkent (51,12 $\mu \mathrm{m}$-röl 17,5 $\mu \mathrm{m}$-re), majd további örlés hatására $\sim 10 \mu \mathrm{m}$-re csökken. $\mathrm{Az}_{90}$ szemcseméret $156,03 \mu \mathrm{m}$-röl 25,38 $\mu \mathrm{m}$-re csökkent a 120 perces őrlés végére. A szemcseméret-elemzés során a szemcsék agglomerálódása nem volt megfigyelhetö.

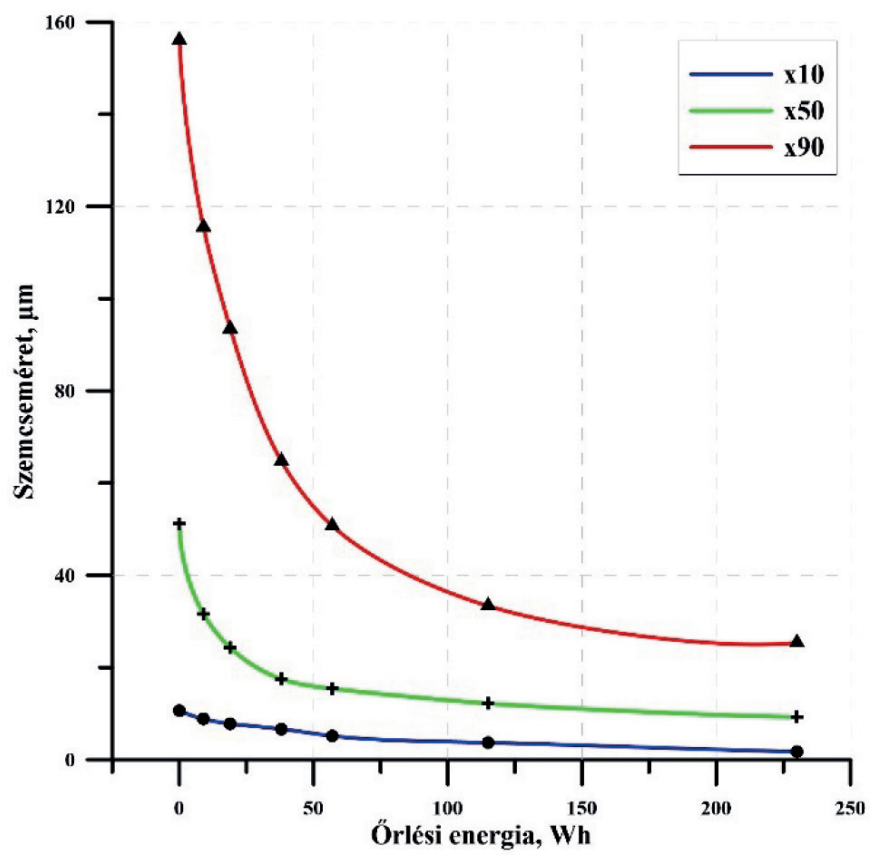

1. ábra Az FA1 örlemények nevezetes szemcseméret értékei

Fig. 1 Characteristic particle size data of the ground FA1 samples

Az őrlemények geometriai fajlagos felület értéke az őrlési idő függvényében exponenciálisan növekedett. A fajlagos felület változása $\mathrm{R}^{2}=0,985$ korrelációs együtthatóval az alábbi függvénnyel jellemezhetö:

$\ln (Y)=0,0161 X+7,821$

\subsection{Geopolimerek nyomószilárdsága, testsürüsége}

A pernye mechanikai aktiválása előtt a nyers pernye reakcióképességének vizsgálata céljából geopolimer próbatesteket állítottam elő $6 \mathrm{M}$ koncentrációjú $\mathrm{NaOH}$ oldat használatával. A nyers pernye alkalmazásával a geopolimer próbatestek nem voltak alkalmasak a nyomószilárdsági kísérletek elvégzésére, mivel nem rendelkeztek megfelelő mechanikai stabilitással (kézzel könnyen morzsolhatók voltak).

Az őrölt pernye finomságának és a fajlagos felület növekedésének hatására változik a keverék reológiai tulajdonsága [20], amely megfigyelhető volt a próbatestek előállítása során. A hosszabb őrlési idővel előállított őrleményekből készült geopolimer paszták hígan folyós állagúak voltak, ellentétben a rövidebb ideig őrölt pernyékből készült keverékek.

A próbatestek nyomószilárdság értékei és a kapcsolódó őrlemények fajlagos felületének változását összehasonlítva (2. ábra) eltérő trend figyelhető meg. Habár az FA1 őrlemény fajlagos felülete nőtt, az egytengelyü nyomószilárdság értéke 10 perc örlés után drasztikusan lecsökkent, 23,3 $\mathrm{MPa}$-ról $12 \mathrm{MPa}$ alá, majd az őrlési idő 120 percre való növelésével ismét 22 MPa fölé nőtt a próbatestek szilárdsága. Az FA2 őrleményből előállított próbatestek esetén megállapítható, hogy a fajlagos felület emelkedésével kezdetben jelentős szilárdság növekedés volt tapasztalható, azonban a fajlagos felület $3000 \mathrm{~cm}^{2} / \mathrm{g}$ fölé növelésével a nyomószilárdság értéke stagnált (3. ábra). Azonban a nagyobb fajlagos felület nem feltétlenül jár a geopolimer próbatestek nagyobb nyomószilárdságával [21,22].

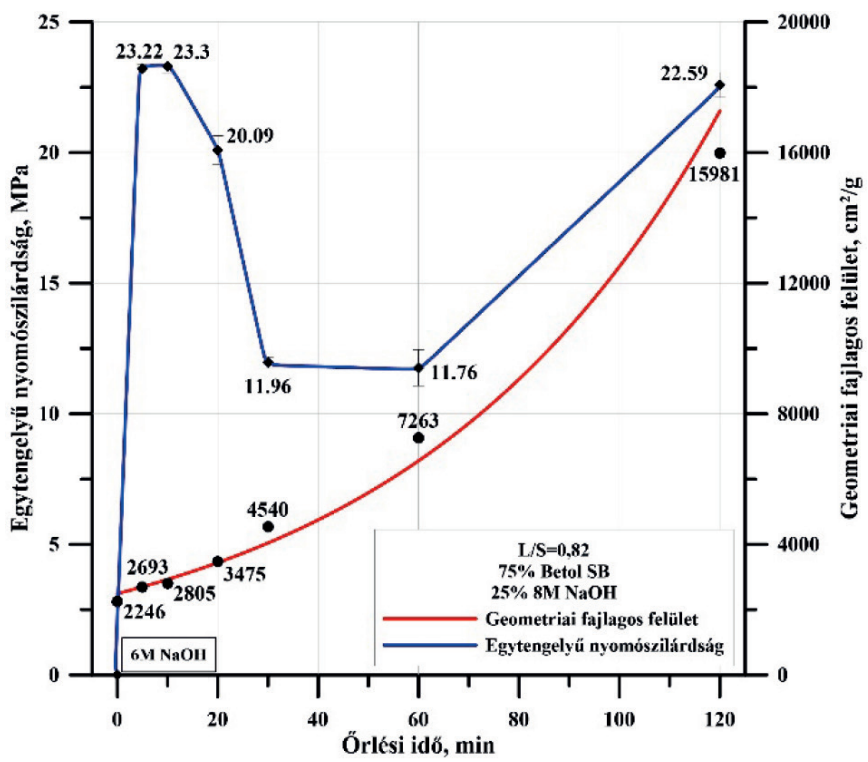

\footnotetext{
2. ábra Az FA1 próbatestek átlagos nyomószilárdság és fajlagos felület értékei Fig. 2 The average compressive strength and specific surface area values of FA1 specimens
}

A próbatestek testsűrüségét megvizsgálva (2. táblázat) a kezdeti $1,63 \mathrm{~g} / \mathrm{cm}^{3}$ testsürüség a 60 perces őrlés eredményeképp $1,71 \mathrm{~g} / \mathrm{cm}^{3}$-re emelkedett, majd 120 perces örlés hatására 1,68 $\mathrm{g} / \mathrm{cm}^{3}$-re csökkent, tehát az elért nyomószilárdság és a testsürüség értékek között sincs korreláció. 


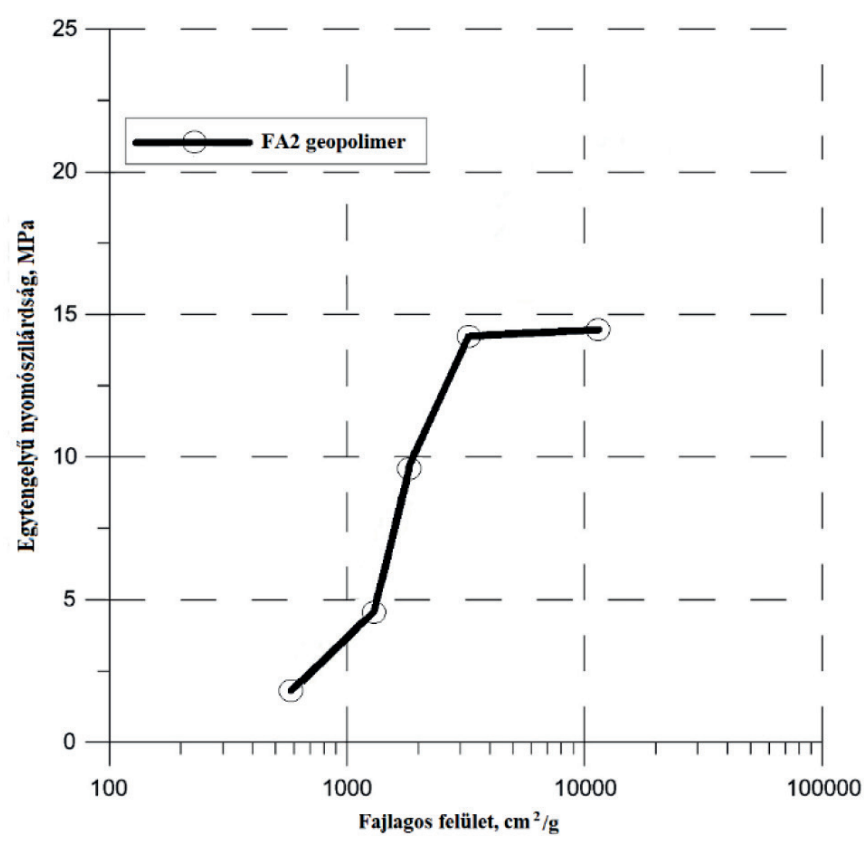

3. ábra Az FA2 próbatestek átlagos nyomószilárdsága a fajlagos felület függvényében [19]

Fig. 3 The average compressive strength of FA2 specimens in relation to specific surface area

\begin{tabular}{|c|c|c|c|c|c|c|}
\hline Őrlési idő, min & 5 & 10 & 20 & 30 & 60 & 120 \\
\hline Testsűrúség, g/cm³ & 1,63 & 1,65 & 1,65 & 1,68 & 1,71 & 1,68 \\
\hline
\end{tabular}

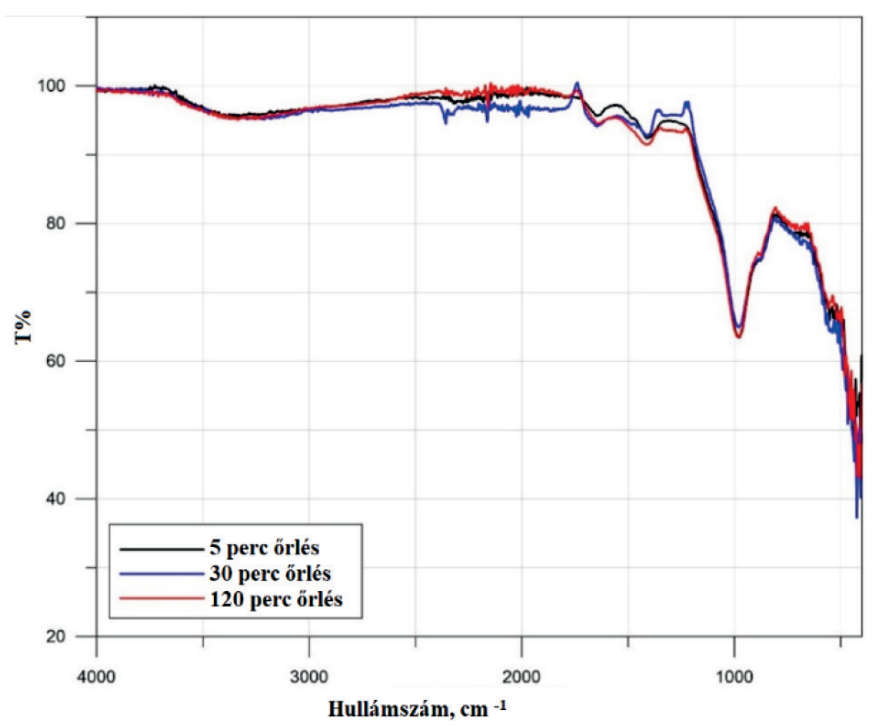

4. ábra Az 5, 30 és 120 perces FA1 őrleményböl készült geopolimer próbatestek FT-IR spektrumai

Fig. 4 The FT-IR spectra of geopolymers from FA1 ground for 5, 30 and 120 minutes

\subsection{FT-IR vizsgálatok}

Az 5, 30 és 120 perces FA1 őrleményekből készült geopolimer próbatestek FT-IR spektrumait a 4. ábra mutatja.

A $3400 \mathrm{~cm}^{-1}$ hullámszámnál megfigyelhető széles csúcsok az -OH és HOH kötések nyújtó rezgései, míg az 1650-1630 $\mathrm{cm}^{-1}$ hullámszámnál megjelenők a hajlító rezgései közel azo- nosak, ezeket a felszínen vagy a pórusokban megkötött vízmolekulák okozhatnak. Az $1400 \mathrm{~cm}^{-1}$ körül megjelenő csúcsok az O-C-O kötések nyújtó rezgései, melyek jelenléte a geopolimer szilárdságának csökkenését okozhatja [23, 24], azonban a vizsgált próbatestek esetén nem volt számottevő eltérés a csúcsok intenzitása között. A $990 \mathrm{~cm}^{-1}$ hullámszámnál látható csúcsok az Si-O-Si és Si-O-Al kötések aszimmetrikus nyújtó rezgései, melyek a geopolimerizáció fokára utalnak, azonban ezen csúcsok intenzitása is közel azonos [25, 26, 27].

A vizsgált próbatestek FT-IR spektrumai szinte azonos lefutásúak, így a szerkezeti vizsgálatok alapján nem mutatható ki számottevő eltérés, mely magyarázatot adna a nyomószilárdság abnormális változására.

\section{Megállapítások}

Kísérleteim során deponált barnaszén pernye golyósmalmi őrlésével foglalkoztam. A 120 perces őrlés eltelte után sem volt megfigyelhető az örlemények szemcseméretének növekedése, sem a fajlagos felület csökkenése, azaz a pernye szemcseméretének folyamatos csökkenését tapasztaltam. A minták őrlése után geopolimer próbatesteket készítettem, hogy az őrlés nyomószilárdságra gyakorolt hatását vizsgáljam. A próbatestek nyomószilárdság értéke és a testsűrüsége között nem állapítható meg egyértelmű kapcsolat, valamint a próbatestek FT-IR vizsgálata sem mutatott ki jelentős különbséget a geopolimerek szerkezetében. A próbatestek további vizsgálata szükséges (pl. XRD) a nyomószilárdság szabálytalan változásának megértéséhez.

\section{Köszönetnyilvánítás}

A cikkben ismertetett kutató munka az EFOP-3.6.1-162016-00011 jelű „Fiatalodó és Megújuló Egyetem - Innovatív Tudásváros - a Miskolci Egyetem intelligens szakosodást szolgáló intézményi fejlesztése" projekt részeként - a Széchenyi 2020 keretében - az Európai Unió támogatásával, az Európai Szociális Alap társfinanszírozásával valósul meg. A szerző köszönetét fejezi ki Dr. Debreczeni Ákosnak és Köteles Lászlónak (ME, Bányászati és Geotechnikai Intézet) az egytengelyü nyomószilárdsági mérések biztosításában és elvégzésében nyújtott segítségéért, Dr. Kristály Ferencnek (ME, Ásványtani - Földtani Intézet) az XRD vizsgálat elvégzéséért, valamint Dr. Mucsi Gábornak és Szabó Rolandnak (ME, Nyersanyagelőkészítési és Környezeti Eljárástechnikai Intézet) a témában való iránymutatásukért.

\section{Irodalomjegyzék}

[1] Nath, S.K. - Kumar, S. (2019): Reaction kinetics of fly ash geopolymerization: Role of particle size controlled by using ball mill. Advanced Powder Technology 30 (5), pp. 1079-1088. http://dx.doi.org/10.1016/j.apt.2019.02.003

[2] Mucsi, G. - Csőke, B. - Erdős, Gy. (2011): Erőműi pernyehasznosítás kutatási tapasztalatai: hidraulikus kötőanyag és geopolimer elóállítása. Bányászati és Kohászati Lapok - BÁNYÁSZAT 144 (3), pp. 13-20.

[3] Davidovits, J. (2011): Geopolymer chemistry and application. Institut Geopolimére, ISBN: 9782951482050 pp. 286.

[4] Kumar, R. - Kumar, S. - Mehrotra, S. P. (2007): Towards sustainable solutions for fly ash through mechanical activation. Resources, Conservation and Recycling 52 (2), pp. 157-179. https://doi.org/10.1016/j.resconrec.2007.06.007 
[5] Bokányi L., Csőke B., Debreczeni Á., Gáspár L., Gombkötő I., Horváth R., Less Gy., Mucsi G., Molnár Z., Rácz Á. (2014): Erőműi pernye komplex hasznosítása (Milagrossa Kft., Miskolc, 2014).

[6] Kumar Sharma, P. - Prasad Singh, J. - Kumar, A. (2019): Effect of Particle Size on Physical and Mechanical Properties of Fly Ash Based Geopolymers. Transactions of the Indian Institute of Metals. https://doi.org/10.1007/s12666-019-01628-w

[7] Kumar, S. - Kristály, F. - Mucsi, G. (2014): Geopolymerisation behaviour of size fractioned fly ash. Advanced Powder Technology 26 (1), pp. 24-30. http://dx.doi.org/10.1016/j.apt.2014.09.001

[8] Temuujin, J. - Williams, R. P. - van Riessen, A. (2009): Effect of mechanical activation of fly ash on the properties of geopolymer cured at ambient temperature. Journal of Materials Processing Technology 209 (12-13), pp. 5276-5280. http://dx.doi.org/10.1016/j.jmatprotec.2009.03.016

[9] Marjanović, N. - Komljenović, M. - Baščarević, Z. - Nikolić, V. (2014): Improving reactivity of fly ash and properties of ensuing geopolymers through mechanical activation, Construction and Building Materials 57, pp. 151-162. https://doi.org/10.1016/j.conbuildmat.2014.01.095

[10] Kusnierová, M. - Slesárová, A. - Prascáková, M. (2005): The significance of fly ash for their processing and utilization. In. Proc. Waste Recycling IX. Krakow, pp. 17-19.

[11] Yeheyis, M. B. - Shang, J. Q. - Yanful, E. K. (2009): Chemical and Mineralogical Transformations of Coal Fly Ash after Landfilling, Előadás, World of Coal Ash Conference (WOCA), May 4-7, 2009. Lexington, Kentucky, USA.

https:/pdfs.semanticscholar.org/cbd5/45b35c33e8887885e26f9dcaec451b0ba036.pdf

[12] Peterová, A. - Škvára, F. - Š́́dlová, M. - Šulc, R. - Sokolová, K. - Snop, R. (2019): Can Czech Stockpiled Fly Ash be Used in the Production of Concrete? In: McCarthy, M. J. - Newlands, M. D. -Jones, M. R. - Dyer, T. D. - Csetenyi, L. J. - Zheng, L. (szerk.): EuroCoalAsh 2019 Proceedings, University of Dundee: Dundee, Egyesült Királyság/Skócia (2019), pp. 123-130.

[13] Tennakoon, C. - Sagoe-Crentsil, K. - San Nicolas, R. - Sanjayan, J. G. (2015): Characteristics of Australian brown coal fly ash blended geopolymers. Construction and Building Materials 101, pp. 396-409. http://dx.doi.org/10.1016/j.conbuildmat.2015.10.089

[14] Saxena, S. K. -Kumar, M. - Singh, N. B. (2018): Effect of Alccofine powder on the properties of Pond fly ash based Geopolymer mortar under different conditions. Environmental Technology \& Innovation 9, pp. 232242. https://doi.org/10.1016/j.eti.2017.12.010

[15] Diaz, E. I. - Allouche, E. N. - Eklund, S. (2010): Factors affecting the suitability of fly ash source material for geopolymers. Fuel 89, pp. 992-996. http://dx.doi.org/10.1016/j.fuel.2009.09.012

[16] Kwasny, J. - McGrath, T. - Lawther, S. - Soutsos, M. - Sha, W. - Cox, S. Chen, J. F. (2019): Lagoon Fly Ash: A Potential Source of the Precursor for Geopolymer. In: McCarthy, M. J. - Newlands, M. D. -Jones, M. R. - Dyer, T. D. - Csetenyi, L. J. - Zheng, L. (szerk.): EuroCoalAsh 2019 Proceedings, University of Dundee: Dundee, Egyesült Királyság/Skócia (2019), pp. 322-333.
[17] Molnár, Z. - Kristály, F. - Mucsi, G. (2014): Mechanical activation of deposited brown coal fly ash in stirred media mill, Acta Physica Polonica A 126 (4), pp. 988-993. https://doi.org/10.12693/APhysPolA.126.988

[18] Mucsi, G. - Gombkötő, I. - Molnár, Z. - Osváth, I. - Kumar, S. (2016): Effect of mechanical activation of fly ash on geopolymer properties, In: Finch, J. - O'Connor, C. - Leroux, D. - Stubina, N. - Polin, G. (szerk): IMPC 2016: XXVIII International Mineral Processing Congress Proceedings, pp. 1-9.

[19] Mucsi, G. -Kumar, S. - Csőke, B. - Kumar,R. -Molnár, Z. - Rácz, Á. Mádai, F. - Debreczeni, Á. (2015): Control of geopolymer properties by grinding of land filled fly ash. International Journal of Mineral Processing 143, pp. 50-58. http://dx.doi.org/10.1016/j.minpro.2015.08.010

[20] Szabó, R. - Gombkötö, I. - Svéda, M. - Mucsi, G. (2017): Effect of grinding fineness of fly ash on the properties of geopolymer foam, Arch. Metall. Mater 62 (2B), pp. 1257-1231. http://dx.doi.org/10.1515/amm-2017-0188

[21] Kumar, S. - Kumar, R. - Alex, T. C. - Bandopadhyay, A. - Mehrotra, S. P. (2007): Influence of reactivity of fly ash ongeopolymerisation. Advances in Applied Ceramics 106 (3), pp. 120-127. http://dx.doi.org/10.1179/174367607X159293

[22] Mádai, F. - Kristály, F. - Mucsi, G. (2015): Microstructure, mineralogy and physical properties of ground fly ash based geopolymers. Ceramics Silikáty 59 (1), pp. 70-79. http://www.ceramics-silikaty.cz/2015/pdf/2015_01_70.pdf

[23] Panias, D. - Giannopoulou, I. P. - Perraki, T. (2007): Effect of synthesis parameters on the mechanical properties of fly ash-based geopolymers. Colloids and Surfaces A: Physicochemical and Engineering Aspects, 301 (1-3), pp. 246-254. http://doi:10.1016/j.colsurfa.2006.12.064

[24] Szabó, R. (2019): Lignit pernye alapú geopolimerek mechanikai tulajdonságainak szabályozása vibrációs tömörítéssel. Építő anyag Journal of Silicate Based and Composite Materials, 71 (2), pp. 66-71. https://doi.org/10.14382/epitoanyag-jsbcm.2019.12

[25] Kumar, S. - Kumar, R. (2011): Mechanical activation of fly ash: Effect on reaction, structure and properties of resulting geopolymer. Ceramics International, 37 (2), pp. 533-541. http://dx.doi.org/10.1016/j.ceramint.2010.09.038

[26] Hamdi, N. - Messaoud, B. I. - Srasra, E. (2018): Production of geopolymer binders using clay minerals and industrial wastes. Comptes Rendus Chimie 22 (2-3), pp. 220-226. http://dx.doi.org/10.1016/j.crci.2018.11.010

[27] Yaseri, S. - Hajiaghei, G. - Mohammadi, F. - Mahdikhani, M. Farokhzad, R. (2017): The role of synthesis parameters on the workability, setting and strength properties of binary binder based geopolymer paste, Construction and Building Materials, 157, 2017, pp 534-545. https://doi.org/10.1016/j.conbuildmat.2017.09.102

Ref.:

Ambrus, Mária: Mechanikai aktiválás hatása deponált pernye alapú geopolimerek nyomószilárdságára

Épitőanyag - Journal of Silicate Based and Composite Materials, Vol. 71, No. 5 (2019), 148-152. p.

https://doi.org/10.14382/epitoanyag-jsbcm.2019.26

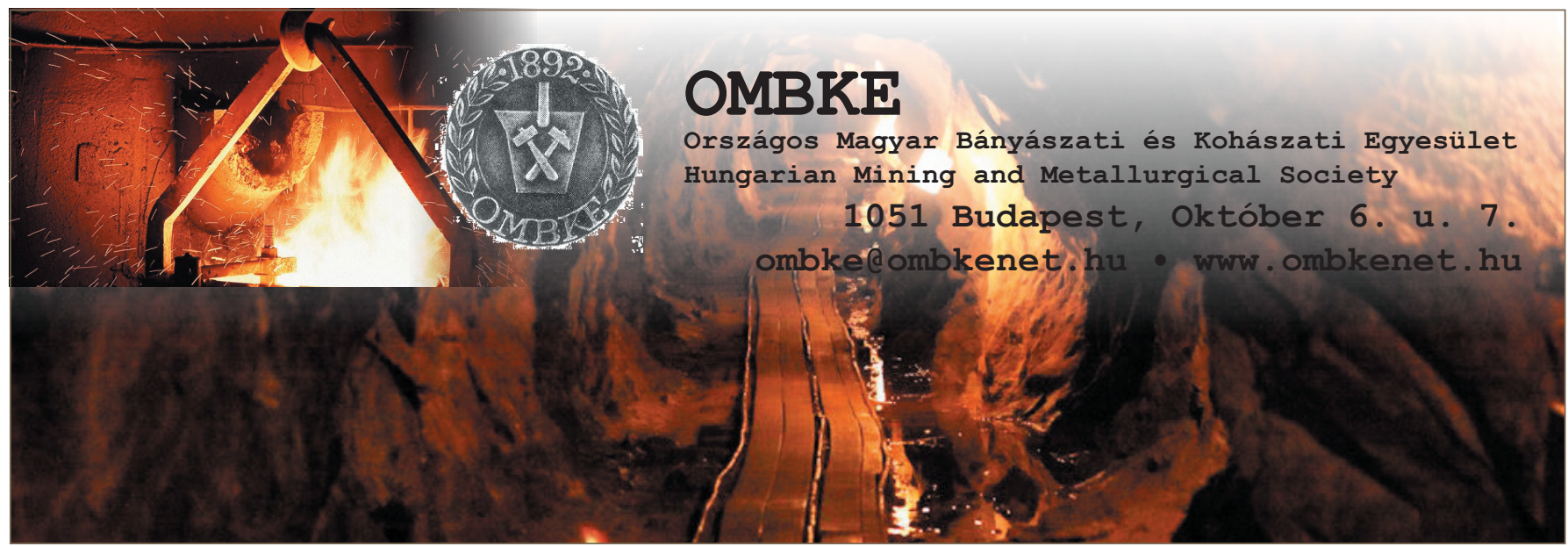

